\title{
Prevalence of inducible clindamycin resistance in methicillin-resistant Staphylococcus aureus: the first study in Jordan
}

\author{
Dua'a Jarajreh ${ }^{1}$, Amin Aqel ${ }^{2,3}$, Hamed Alzoubi² ${ }^{2}$, Wael Al-Zereini ${ }^{1}$ \\ ${ }^{1}$ Biological Sciences Department, Faculty of Science, Mu'tah University, Alkarak, Jordan \\ 2 Microbiology and Immunology Department, Faculty of Medicine, Mu'tah University, Alkarak, Jordan \\ ${ }^{3}$ Al-Ghad International Colleges for Applied Medical Sciences, Al-Madinah Branch, Saudi Arabia
}

\begin{abstract}
Introduction: A high rate of infections with methicillin-resistant Staphylococcus aureus (MRSA) has been documented, in both hospital- (HAMRSA) and community-acquired (CA-MRSA) diseases in Jordan. Erythromycin and clindamycin are considered treatments of choice. However, resistance to erythromycin with false susceptibility to clindamycin in vitro may lead to therapeutic failure. Hence, it is mandatory to study the prevalence of inducible resistance to macrolide-lincosamide-streptogramin B (iMLS $\mathrm{B}$ ) antibiotics conferred by erm genes in those bacteria.

Methodology: S. aureus isolates were identified morphologically and biochemically, and MRSA were appraised using standard procedures. Induction in resistance to $\mathrm{MLS}_{\mathrm{B}}$ antibiotics among MRSA isolates was detected phenotypically using the D-test, and the presence of erm genes was revealed by polymerase chain reaction (PCR).

Results: Of 126 collected Staphylococcus isolates, 71 (56.3\%) isolates were S. aureus, of which 55 (77.5\%) were MRSA. A total of 43 (78.2\%) MRSA-discordant isolates were resistant to erythromycin, of which 33 (76.7\%) exhibited the iMLSв (D-test positive), 2 (4.7\%) the MS в (Dtest negative), and $8(18.6 \%)$ the constitutive resistant $\left(\mathrm{cMLS}_{\mathrm{B}}\right)$ phenotypes. Induction of clindamycin resistance was 1.6 times greater in CAMRSA than in HA-MRSA. Furthermore, ermA and ermC were significantly prevalent in HA-MRSA and CA-MRSA, respectively.

Conclusions: Continuous surveillance of the $\mathrm{MLS}_{\mathrm{B}}$ resistance is important and required before the prescription of clindamycin to treat MRSA infections.
\end{abstract}

Key words: Clindamycin resistance; iMLS ; MRSA.

J Infect Dev Ctries 2017; 11(4):350-354. doi:10.3855/jidc.8316

(Received 01 March 2016 - Accepted 15 April 2016)

Copyright (C) 2017 Jarajreh et al. This is an open-access article distributed under the Creative Commons Attribution License, which permits unrestricted use, distribution, and reproduction in any medium, provided the original work is properly cited.

\section{Introduction}

In Jordan, methicillin-resistant Staphylococcus aureus (MRSA) represents $57 \%-62 \%$ and $19 \%$ of clinical and nasal carriage isolates, respectively [1]. MRSA infections are treated with macrolidelincosamide-streptogramin B (MLS $\left.\mathrm{B}_{\mathrm{B}}\right)$ antibiotics, with clindamycin as the drug of choice due to its pharmacokinetic properties [2]. However, resistance to erythromycin (macrolide) in staphylococci is usually associated with resistance to clindamycin (lincosamides) and to type B streptogramin [3]. This cross-resistance to $\mathrm{MLS}_{\mathrm{B}}$ antibiotics is mediated by erythromycin ribosomal methylase (erm) encoding genes [4]. Three MLS $_{\text {B }}$ phenotypes are known in $S$. aureus, a constitutive resistant phenotype $\left(\mathrm{cMLS}_{\mathrm{B}}\right)$, a clindamycin-susceptible phenotype in vitro with inducible resistance in vivo (iMLS $\mathrm{B}$ ), and a clindamycin-susceptible and macrolide-steptogramin B-resistant phenotype $\left(\mathrm{MS}_{\mathrm{B}}\right)$.
A false susceptibility to clindamycin in iMLS $_{B}$ MRSA phenotypes may lead to therapeutic failure [5]. Therefore, accurate detection of iMLS $_{\mathrm{B}-\text { resistant }}$ isolates of $S$. aureus in vivo is a priority concern in therapeutic strategies. Herein, as the first study in Jordan to our best knowledge, this study reports the prevalence of iMLS $_{\mathrm{B}}, \mathrm{cMLS}_{\mathrm{B}}$, and MS phenotypes with detection of erm genes in clinical and nasal carriage MRSA isolates.

\section{Methodology}

A total of 126 non-duplicated Staphylococcus isolates were obtained from different sources of hospitalized adult Jordanian patients (Al-Karak Hospital and Prince Ali Hospital) in Al-Karak Governorate, Jordan. In addition, nasal swabs of carrier individuals were collected from the same area. Each participant signed a written informed consent document, and the study was approved by the ethics and 
scientific committees of the Faculty of Medicine and Faculty of Graduate studies, Mu'tah University, Jordan.

$S$. aureus isolates, grown on mannitol salt agar plates (Oxoid, Basingstoke, UK) at $37^{\circ} \mathrm{C}$, were identified morphologically and biochemically using standard procedures $[6,7]$ and confirmed by detection of the occurrence of $S$. aureus species-specific (sau) gene by polymerase chain reaction (PCR) [8]. MRSA isolates were identified using oxacillin $(1 \mu \mathrm{g})$ and cefoxitin $(30 \mu \mathrm{g})$ disks (Oxoid, Basingstoke, UK), and their susceptibility profile was determined using a variety of antibiotics (Oxoid, Basingstoke, UK): gentamycin $(10 \mu \mathrm{g})$, chloramphenicol $(30 \mu \mathrm{g})$, tetracycline $(30 \mu \mathrm{g})$, kanamycin $(30 \mu \mathrm{g})$, clindamycin $(2 \mu \mathrm{g})$, erythromycin $(15 \mu \mathrm{g})$, vancomycin $(30 \mu \mathrm{g})$, and ampicillin $(10 \mu \mathrm{g})$, following the Clinical and Laboratory Standards Institute (CLSI) guidelines [9].

Different $\mathrm{MLS}_{\mathrm{B}}$ phenotypes were perceived for erythromycin-resistant MRSA isolates using the double diffusion test (D-test) based on CLSI guidelines [9]. Meanwhile, genotypic detection of erm genes was carried out for $\mathrm{iMLS}_{\mathrm{B}}$ phenotypes. Genomic DNA from iMLS $_{\mathrm{B}}-\mathrm{MRSA}$ was isolated following a standard protocol [10], adopting the rapid lysis method recommended by Al-Talib et al. [11]. DNA amplification was carried out by PCR (XP Thermal cycler, Bioer Technology, Binjiang, China) using specific primer pairs for the ermB [4], ermA, ermC, sau, and methicillin-specific resistance $(m e c A)$ genes as described previously [8]. Single PCR reactions were employed using 2x master mix (i-MAX II, iNtRON Biotechnology, Gyeonggi-do, Korea), while multiplex PCR reactions were employed using $2 \mathrm{x}$ master mix (Master/MultiMAX, iNtRON Biotechnology, Gyeonggi-do, Korea) (Table 1). Genomic DNA from MRSA (S. aureus ATCC 43300) was used as a control.

The amplified PCR fragments were resolved by electrophoresis through a $1.5 \%$ agarose gel containing $0.5 \mu \mathrm{g} / \mathrm{mL}$ ethidium bromide and visualized under UV
Figure 1. Mueller-Hinton agar plates demonstrating different MLS $_{B}$ phenotypes.
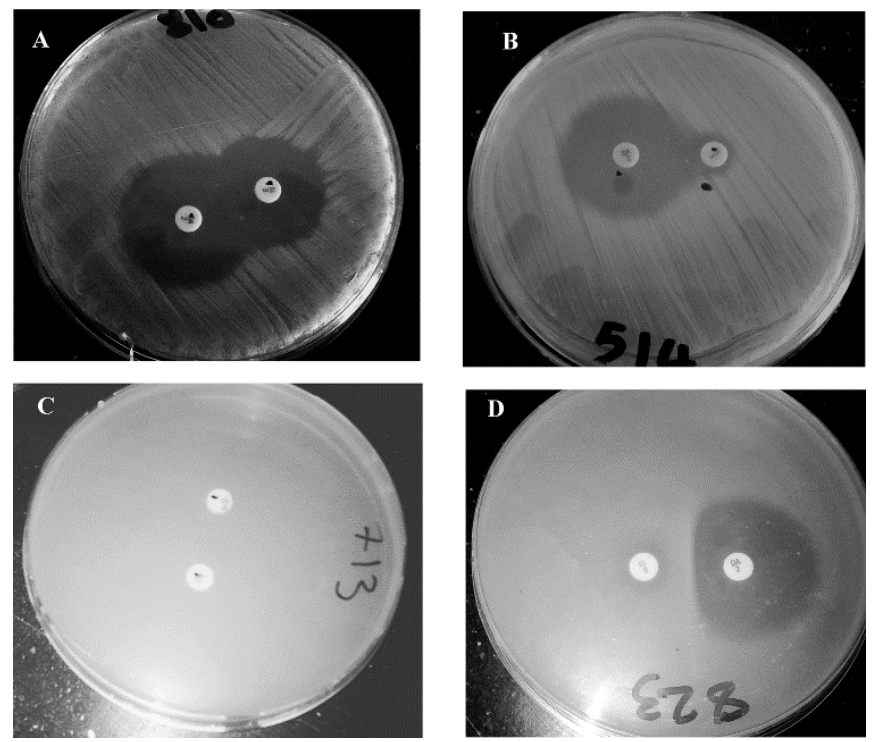

(A) Er-S, CL-S phenotype; (B) Er-R, CL-S phenotype (MS, D-); (C) Er$\mathrm{R}, \mathrm{CL}-\mathrm{R}$ phenotype (cMLS $)$; (D) Er-R, CL-S phenotype (iMLS $\mathrm{B}_{\mathrm{B}}, \mathrm{D}^{+}$). CL: clindamycin; cMLS $_{\mathrm{B}}$ : constitutive macrolide-lincosamidestreptogramin $\mathrm{B}$ resistant phenotype; $\mathrm{D}^{-}$: D-test negative; $\mathrm{D}^{+}$: D-test positive; Er: erythromycin; iMLS $_{\mathrm{B}}$ : inducible macrolide-lincosamidestreptogramin B resistant phenotype; $\mathrm{MLS}_{\mathrm{B}}$ : macrolide-lincosamidestreptogramin $\mathrm{B} ; \mathrm{MS}_{\mathrm{B}}$ : macrolide-streptogramin B resistant phenotype; R: resistant; S: susceptible.

light (gel documentation, Transilluminator UVP, Upland, USA).

\section{Statistical analysis}

Data were analyzed using the Chi-squared test $\left(\chi^{2}\right)$ and Fisher's exact test. P values $\leq 0.05$ were considered statistically significant.

\section{Results}

A total of 71 isolates from the collected samples were identified as $S$. aureus (56\%), of which 55 (77.5\%) isolates were MRSA and $16(22.5 \%)$ were methicillinsusceptible $S$. aureus (MSSA). Moreover, resistance to

Table 1. Polymerase chain reaction (PCR) components and their conditions used in detection of erm and methicillin resistance genes.

\begin{tabular}{|c|c|}
\hline PCR reactions components & Conditions of PCR reactions \\
\hline $\begin{array}{l}\text { Single PCR: A total volume of } 20 \mu \mathrm{L} \text { containing } 10 \mu \mathrm{L} \\
\text { of master mix, } 100 \text { ng of template DNA, } 1.5 \mu \mathrm{L} \text { of each primer }(10 \\
\text { pmol } / \mu \mathrm{L} \text {, Midland Company/Midland, USA }) \text { and nucleic acid free } \\
\text { water. }\end{array}$ & $\begin{array}{l}\text { Initial denaturation step of } 3 \mathrm{~min} \text { at } 95^{\circ} \mathrm{C} \text {, followed by } \\
35 \text { cycles at } 95^{\circ} \mathrm{C} \text { for } 15 \mathrm{~s} \text { of denaturation, } 15 \mathrm{~s} \text { of annealing at } \\
54^{\circ} \mathrm{C}, 30 \mathrm{~s} \text { of elongation at } 72^{\circ} \mathrm{C} \text {, and a final extension step of } 5 \\
\text { min at } 72^{\circ} \mathrm{C} \text {. An annealing temperature of } 47^{\circ} \mathrm{C} \text { was applied in } \\
\text { case of } \operatorname{ermB} \text { amplification. }\end{array}$ \\
\hline $\begin{array}{l}\text { Multiplex PCR: A total volume of } 20 \mu \mathrm{L} \text { containing } 10 \mu \mathrm{L} \text { of } \\
\text { master mix, } 100 \text { ng of template DNA, } 6 \mu \mathrm{L} \text { of primer mixture }(10 \\
\text { pmol } / \mu \mathrm{L} \text {, Midland Company, Midland, USA), and nucleic acid } \\
\text { free water. Primer mixture included } 1 \mu \mathrm{L} \text { from each erm } C \text { primer, } \\
1.5 \mu \mathrm{L} \text { from each of sau and mecA primers, and } 2 \mu \mathrm{L} \text { from each } \\
\text { erm } A \text { primer. }\end{array}$ & $\begin{array}{l}\text { Initial denaturation step of } 5 \mathrm{~min} \text { at } 95^{\circ} \mathrm{C} \text {, followed by } \\
35 \text { cycles at } 95^{\circ} \mathrm{C} \text { for } 30 \mathrm{~s} \text { of denaturation, } 1 \text { min of annealing at } \\
54^{\circ} \mathrm{C}, 1 \mathrm{~min} \text { of elongation at } 72^{\circ} \mathrm{C} \text {, and a final extension step of } 5 \\
\text { min at } 72^{\circ} \mathrm{C} \text {. }\end{array}$ \\
\hline
\end{tabular}


methicillin was confirmed by detecting a 532 bp PCR product of the mec $A$ gene. MRSA were highly resistant to erythromycin (78\%), kanamycin $(80 \%)$, and tetracycline (63.6\%). Meanwhile, $82 \%$ and $100 \%$ of MRSA samples were susceptible to clindamycin and to vancomycin, respectively. MRSA prevailed in $67.3 \%$ of hospital-acquired (HA) infections and $32.7 \%$ of community-acquired (CA) diseases. A high rate of resistance to methicillin was detected in $24.6 \%$ and $32.7 \%$ of nasal and wound isolates, respectively. Furthermore, all isolates of CA-MRSA were susceptibility to clindamycin versus $70 \%$ of HAMRSA.

A total of 43 MRSA isolates were resistant to erythromycin, among which $33(76.7 \%)$ exhibited iMLS $_{\text {В }}$ phenotypes, $2(4.7 \%)$ were $\mathrm{MS}_{\mathrm{B}}$, and $8(18.6 \%)$ demonstrated $\mathrm{cMLS}_{\mathrm{B}}$ phenotypes (Figure 1). All of CAMRSA and $61.5 \%$ of HA-MRSA showed iMLS phenotypes. Statistically, the incidence of inducing clindamycin resistance was 1.6 times greater in CAMRSA than in HA-MRSA $(\mathrm{p}=0.003)$.

Occurrence of merely one erm gene or association of more than one erm gene, mecA, and sau genes in $\mathrm{iMLS}_{\mathrm{B}}$ is shown in Figure 2. Presence of only the ermC gene was frequently demonstrated in both CA-MRSA and HA-MRSA $(5 / 15,29.4 \%$ and $2 / 16,12.5 \%)$ and significantly in combination with ermA in HA-MRSA $(5 / 16,31.3 \%, \mathrm{p}=0.018)$ or with $\operatorname{ermB}$ in CA-MRSA $(6 / 17,35.3 \%, \mathrm{p}=0.05)$. A single ermA or ermB gene
Figure 2. Representative gel electrophoresis revealing the amplicons of ermA, ermB, ermC (199 bp, 142 bp, 299 bp), sau (107 bp), and mecA (532 bp).

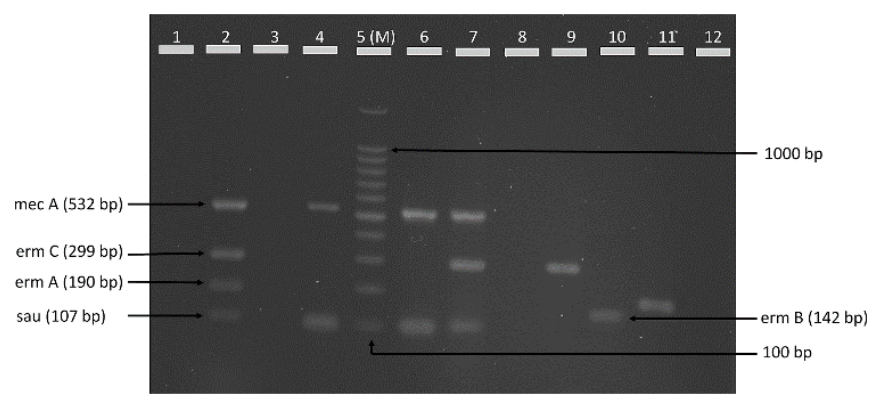

Multiplex polymerase chain reaction (PCR) of gene combinations: lane 2: sample 61; lane 7: sample 712; lanes 4 and 6: methicillin-resistant Staphylococcus aureus (ATCC 43300, control); Lanes 9-11: single polymerase chain reaction (PCR) for erm genes in sample 61; lane 5: molecular size DNA ladder 100 bp. bp: base pair; erm: erythromycin ribosomal methylase encoding gene; mec: methicillin resistance coding gene; sau: Staphylococcus aureus specific gene.

was detected in only one isolate. Occurrence of the three $\mathrm{erm}$ genes in the same isolate was more prevalent in HA-MRSA $(6 / 16,37.5 \%)$ than in CA-MRSA $(3 / 17$, $17.6 \%$ ) (Table 2).

Statistically, it was noticed that ermA was significantly detected 2.55 more times in HA-MRSA ( $p$ $=0.01)$ than in CA-MRSA, with insignificant differences in the prevalence of ermB or erm $C$ between the two MRSA groups. However, within the same group, erm $C$ was significantly detected in CA-MRSA

Table 2. Prevalence of erm genes in erythromycin-resistant iMLS $\mathrm{B}_{\mathrm{B}}-\mathrm{MRSA}$.

\begin{tabular}{cccccc}
\hline Genotype & $\begin{array}{c}\text { CA-MRSA } \\
\mathbf{n = 1 7}\end{array}$ & $\begin{array}{c}\text { HA-MRSA } \\
\mathbf{n = 1 6}\end{array}$ & Pvalue & Relative risk & CI (95\%) \\
\hline ermA & $1(6 \%)$ & 0 & 0.52 & 0.94 & $0.84-1.1$ \\
$e r m B$ & 0 & $1(6.3 \%)$ & 0.51 & 0.94 & $0.84-1.1$ \\
$e r m C$ & $5(29.4 \%)$ & $2(12.5 \%)$ & 0.22 & 2.35 & $0.53-10.45$ \\
$e r m A+e r m B$ & $2(11.7 \%)$ & $1(6.3 \%)$ & 0.52 & 1.88 & $0.19-18.80$ \\
$e r m A+e r m C$ & 0 & $5(31.3 \%)^{*}$ & 0.018 & 1.45 & $1.05-2.20$ \\
$e r m B+e r m C$ & $6(35.3 \%)^{*}$ & $1(6.3 \%)$ & 0.05 & 5.65 & $0.76-41.89$ \\
$e r m A+e r m B+e r m C$ & $3(17.6 \%)$ & $6(37.5 \%)$ & 0.19 & 0.47 & $0.14-1.57$ \\
\hline
\end{tabular}

"Significant ( $\mathrm{p} \leq 0.05)$. CA-MRSA: community-acquired methicillin-resistant Staphylococcus aureus; CI: confidence intervals; erm: erythromycin ribosomal methylase encoding gene; HA-MRSA: hospital-acquired methicillin-resistant Staphylococcus aureus; iMLS ${ }_{\mathrm{B}}$ : induciblemacrolide-lincosamide-streptogramin B resistant phenotype; MRSA: methicillin resistant Staphylococcus aureus.

Table 3. Frequency and overall prevalence of erm genes detection in erythromycin-resistant iMLSB-MRSA.

\begin{tabular}{cccccc}
\hline Genotype & $\begin{array}{c}\text { CA-MRSA } \\
\mathbf{n = 1 7}\end{array}$ & $\begin{array}{c}\text { HA-MRSA } \\
\mathbf{n = 1 6}\end{array}$ & Pvalue & Relative risk & CI (95\%) \\
\hline ermA & $5(29.4 \%)$ & $12(75 \%)^{*}$ & 0.01 & 2.55 & $1.16-5.61$ \\
$e r m B$ & $10(58.8 \%)$ & $9(56.3 \%)$ & 0.58 & 1.05 & $0.58-1.88$ \\
$e r m C$ & $14(82.4 \%)^{* *}$ & $14(87.5 \%)$ & 0.53 & 0.94 & $0.70-1.25$ \\
Overall prevalence (pvalue) & 0.007 & 0.13 & &
\end{tabular}

${ }^{*}$ Significant $(\mathrm{p} \leq 0.05)$ among groups; ${ }^{* *}$ Significant $(\mathrm{p} \leq 0.05)$ within same group. CA-MRSA: community-acquired methicillin-resistant Staphylococcus aureus; CI: confidence intervals; erm: erythromycin ribosomal methylase encoding gene; HA-MRSA: hospital-acquired methicillin-resistant Staphylococcus aureus; iMLS $_{\mathrm{B}}$ : induciblemacrolide-lincosamide-streptogramin B resistant phenotype; MRSA: methicillin-resistant Staphylococcus aureus. 
$(\mathrm{p}=0.007)$ (Table 3). Interestingly, ermB was detected at relatively high frequency in both HA-MRSA and CA-MRSA (56.3\% and 58.8\%, respectively).

\section{Discussion}

The emergence of MRSA led to difficulties in treating $S$. aureus infections, especially in developing countries [12]. Therefore, clindamycin has been used to treat soft tissue and pediatric infections and is used in patients allergic to $\beta$-lactams due to its pharmacokinetics and low cost when compared to other newer agents used to treat MRSA infections [13]. However, harboring erm genes may lead to therapeutic failure due to inducible resistance to clindamycin in those patients.

Coinciding with our results, a high prevalence rate $(57 \%-70 \%)$ of MRSA was documented among Jordanian hospitalized adults [14]; the MRSA samples and were recovered mainly from upper respiratory tract and wound swabs [15]. Moreover, herein we reported a higher incidence of inducible clindamycin resistance in MRSA $(76.7 \%)$ with a higher rate of iMLS $_{\text {В }}$ phenotypes in CA-MRSA than in HA-MRSA. Conversely, in studies conducted in Europe, Turkey, Japan, and India, the incidence of iMLS $_{B}$ was $24 \%-39 \%$ in MRSA, and inducible phenotypes were detected more frequently in HA-MRSA [16-18]. This could be attributed to differences in drug usage recommendations in each country and inconsistent use of erythromycin in different infectious cases.

High prevalence of ermA was documented previously in HA-MRSA [19]. In addition, presence of ermA on the transposon Tn554 within SCCmec (staphylococcal cassette chromosome mec) I, II, and III, and absence on SCCmec IV explains the low prevalence of this gene in CA-MRSA [20]. The occurrence of the ermB gene, originally identified from Streptococcus species isolated from animals [21], in high frequency in this study may reflect the high capacity of this gene to be horizontally transferred from Streptococcus species to $S$. aureus.

\section{Conclusions}

The demonstrated high incidence of $\mathrm{iMLS}_{\mathrm{B}}$ in clinical practice and community supports limiting the use of erythromycin for prophylaxis and treatment of MRSA. Performing the D-test on isolates conferring erythromycin-resistant and clindamycin-susceptible phenotypes is prudent to exclude inducible clindamycin resistance.

\section{Acknowledgements}

The authors would like to thank Dr. Nedal Awad Alnawaiseh for his efforts and help in statistical analysis.

\section{References}

1. Aqel A, Ibrahim A, Shehabi A (2012) Rare occurrence of mupirocin resistance among clinical Staphylococcus isolates in Jordan. Acta Microbiol Immunol Hung 59: 239-247.

2. Ansari S, Nepal H, Gautam R, Rayamajhi N, Shrestha S, Upadhyay G, Acharya A, Chapagain M (2014) Threat of drug resistant Staphylococcus aureus to health in Nepal. BMC Infect Dis 14: 157-161.

3. Deotale V, Mendiratta DK, Raut U, Narang P (2010) Inducible clindamycin resistance in Staphylococcus aureus isolated from clinical samples. Indian J Med Microbiol 28: 124-126.

4. Martineau F, Picard FJ, Lansac N, Ménard C, Roy PH, Ouellette M, Berergon M (2000) Correlation between the resistance genotype determined by multiplex PCR assays and the antibiotic susceptibility patterns of Staphylococcus aureus and Staphylococcus epidermidis. Antimicrob Agents Chemother 44: 231-238.

5. Aleksandra AD, Misic MS, Mira ZV, Violeta NM, Dragana IT, Zoran BM, Dejan V, Milanko S, Dejan B (2014) Prevalence of inducible clindamycin resistance among communityassociated staphylococcal isolates in central Serbia. Indian J Med Microbiol 32: 49-52.

6. Collins CH, Lyne PM, Grange JM (2004) Collins and Lyne's microbiological methods, 8th edition. London: ButterworthHeinemann. 480 p.

7. York MK, Taylor MM, Hardy J, Henry M (2007) Biochemical tests for the identification of aerobic bacteria. In Garcia LS, Isenberg $\mathrm{HD}$, editors. Clinical microbiology procedures handbook, 2nd edition, update 2007. Washington, DC: ASM Press. 3.17.1.1-3.17.48.3

8. Strommenger B, Kettlitz C, Werner G, Witte W (2003) Multiplex PCR assay for simultaneous detection of nine clinically relevant antibiotic resistance genes in Staphylococcus aureus. J Clin Microbiol 41: 4089-4094.

9. Clinical and Laboratory Standards Institute (2012) Performance standards for antimicrobial susceptibility testing; Twenty-second informational supplement (M100-S22). Wayne, PA: CLSI.

10. Sambrook J, Russell DW (2001) Molecular cloning: a laboratory manual, Vol 1, 3rd edition. New York: Cold Spring Harbor Laboratory Press. 999 p.

11. Al-Talib H, Yean CY, Al-Khateeb A, Ravichandran M (2013) Comparative evaluation of three different methods of genomic DNA extraction for Staphylococcus aureus. World Appl Sci J 21: 424-427.

12. Diekema DJ, Pfaller MA, Schmitz FJ, Smayevsky J, Bell J, Jones RN, Beach M, SENTRY Participants Group (2001) 
Survey of infections due to Staphylococcus species: frequency of occurrence and antimicrobial susceptibility of isolates collected in the United States, Canada, Latin America, Europe, and the Western Pacific region for the SENTRY Antimicrobial Surveillance Program, 1997-1999. Clin Infect Dis 32 Suppl 2: 114-132.

13. Lewis JS, Jorgresen JH (2005) Inducible resistance in staphylococci: should clinicians and microbiologists be concerned? Clin Infect Dis 40: 280-285.

14. Alzoubi K, Hayajneh W, Ayoub A, Al-Safi S, Al-Azzam S, Mhaidat N (2010) Prevalence of methicillin-resistant Staphylococcus aureus (MRSA) at a tertiary hospital in north Jordan. Jord J Pharm Sci 3: 37-43.

15. Saleh S, Basheti E, Aburuz S, Khoury M, Haddadin R (2013) Comparing prevalence of methicillin-resistant Staphylococcus aureus (MRSA) over the years 2008 to 2010 at a local hospital in Amman, Jordan. Jord J Appl Sci 11: 1-10.

16. Otsuka T, Zaraket H, Takano T, Saito K, Dohmae S, Higuchi W, Yamamoto T (2007) Macrolide-lincosamidestreptogramin B resistance phenotypes and genotypes among Staphylococcus aureus clinical isolates in Japan. Clin Microbiol Infect 13: 325-327.

17. Yilmaz G, Aydin K, Iskender S, Caylan R, Koksal I (2007) Detection and prevalence of inducible clindamycin resistance in staphylococci. J Med Microbiol 56: 342-345.
18. Lall M, Sahni AK (2014) Prevalence of inducible clindamycin resistance in Staphylococcus aureus isolated from clinical samples. Med J Armed Forces India 70: 43-47.

19. Sun DD, Ma XX, Hu J, Tian Y, Pang L, Shang H, Cui L (2013) Epidemiological and molecular characterization of community and hospital acquired Staphylococcus aureus strains prevailing in Shenyang, Northeastern China. Braz J Infect Dis 17: 682690.

20. Patel M, Waites KB, Moser SA, Cloud GA, Hoesley CJ (2006) Prevalence of inducible clindamycin resistance among community- and hospital-associated Staphylococcus aureus isolates. J Clin Microbiol 44: 2481-2484.

21. Coutinho VD, Paiva RM, Reiter KC, de-Paris F, Barth AL, Machado AB (2010) Distribution of erm genes and low prevalence of inducible resistance to clindamycin among staphylococci isolates. Braz J Infect Dis 14: 564-568.

\section{Corresponding author}

Wael A. Al-Zereini, Associate Professor

Biological Sciences Department, Faculty of Science, Mu'tah

University, P. O. Box 7 Mu'tah 61710, Al-Karak, Jordan

Phone: +962-3-2372380 ext 4224

Fax: +962-3-2375540

Email: wzereini@mutah.edu.jo

Conflict of interests: No conflict of interests is declared. 